\title{
Magma Paths at Piton de la Fournaise Volcano
}

\author{
Laurent Michon, Valérie Ferrazzini and Andrea Di Muro
}

\begin{abstract}
Several patterns of magma paths have been proposed since the 1980s for Piton de la Fournaise volcano. Given the significant differences, which are presented here, we propose a reappraisal of the magma intrusion paths using a 17-years-long database of volcano-tectonic seismic events and a detailed mapping of the scoria cones. At the edifice scale, the magma propagates along two N120 trending rift zones. They are wide, linear, spotted by small to large scoria cones and related lava flows and involving magma resulting from high-pressure fractionation of $\mathrm{ol} \pm \mathrm{cpx}$ and presents an eruption periodicity of around 200 years over the last 30 kiloyears. The upper plumbing system originates at the base of the edifice below the Enclos Fouqué caldera. It feeds frequent (1 eruption every 9 months on average), short-lived summit and distal (flank) eruptions along summit and outer rift zones, respectively. Summit rift zones are short and present an orthogonal pattern restricted to the central active cone of Piton de la Fournaise whereas outer rift zones extend from inside the Enclos Fouqué caldera to the NE and SE volcano flanks. To sum up, rift zones of Piton de la Fournaise present strong geometrical and dynamical differences. On the one hand, the lower plumbing system feeds rift zones showing striking similarities to those developed in Hawaii during the alkaline postshield
\end{abstract}

L. Michon $(\bowtie)$

Laboratoire Géosciences Réunion, Université de La

Réunion, Institut de Physique du Globe de Paris,

Sorbonne Paris Cité, UMR 7154 CNRS, F-97744

Saint Denis, France

e-mail: laurent.michon@univ-reunion.fr

V. Ferrazzini · A. Di Muro

Observatoire Volcanologique du Piton de la

Fournaise, Institut de Physique du Globe de Paris,

Sorbonne Paris Cité, UMR 7154 CNRS, F-75005

Paris, France 
stage. On the other hand, the rift zones connected to upper plumbing system can be compared the rift system of Mount Etna, whose dynamics is know to be linked with the lateral displacement of the east flank.

\subsection{Introduction}

On ocean basaltic volcanoes, magma transfer from the source to the surface is generally assumed to occur along sub-vertical ascent paths through the mantle lithosphere, the oceanic crust and the volcanic edifice, eventually followed by lateral propagation at shallower levels along preferential intrusion paths named rift zones (e.g. MacDonald 1972). At the surface, volcanic rift zones are outlined by a concentration of scoria cones and eruptive fissures, which results from their overall history of activity. Their wide range of geometry, from radial or circumferential diffuse rift zones (e.g. Galapagos; Chadwick and Howard 1991) to narrow km-long rift zones (e.g. Hawaiian shields; Walker 1999) is known as dependent, among other parameters, on the dynamics of the plumbing system, the gravitational deformation of the volcanic edifice and the influence of the crustal inheritance (Fiske and Jackson 1972; MacDonald 1972; Dieterich 1988; Chadwick and Dieterich 1995; Walker 1999; Walter and Troll 2003; Michon et al. 2007; Chaput et al. 2014a). For the world's most active volcanoes, such as Kilauea and Etna, the rift zones are well identified and provide the opportunity of searching/studying the interrelation between rift zone development, flank displacement and plumbing system dynamics (Dieterich 1988; Walter et al. 2005; Montgomery-Brown et al. 2011). By contrast, the geometry of the rift zones of Piton de la Fournaise (La Réunion hotspot) is still debated and the link between their development and the dynamics of the plumbing system still unclear.

This paper aims first at reviewing the spatial distribution of preferential intrusion paths proposed for Piton de la Fournaise during the last decades using different methodological approaches and, second, at determining the geometry of the plumbing system and its link with the rift zones.

\subsection{Review of the Intrusion Paths at Piton de la Fournaise}

\subsubsection{Magma Paths at the Edifice Scale}

Two different approaches have been conducted to determine the rift zone geometry at the edifice scale, taking into account either the concentration of the scoria cones (Villeneuve and Bachèlery 2006) or the distribution and the morphometrical parameters of the cinder cones(Bonali et al. 2011). Despite the use of the same 25-m-step digital elevation model of the French Institut Géographique National (IGN), each methodology has produced contrasting results. Only three rift zones were identified from the volcanic cone concentration: two arched rift zones connected to the volcano's summit, prolonged in the NE and SE directions toward the ocean, and a N120 rift zone located between the summits of the Piton des Neiges and Piton de la Fournaise volcanoes (Fig. 7.1a; Villeneuve and Bachèlery 2006). An additional minor direction of intrusion, 


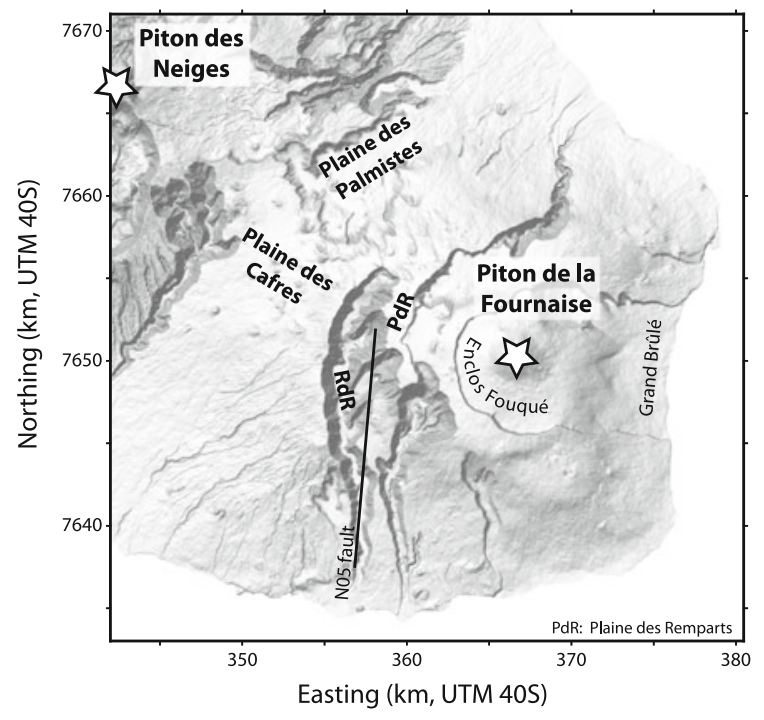

(a)

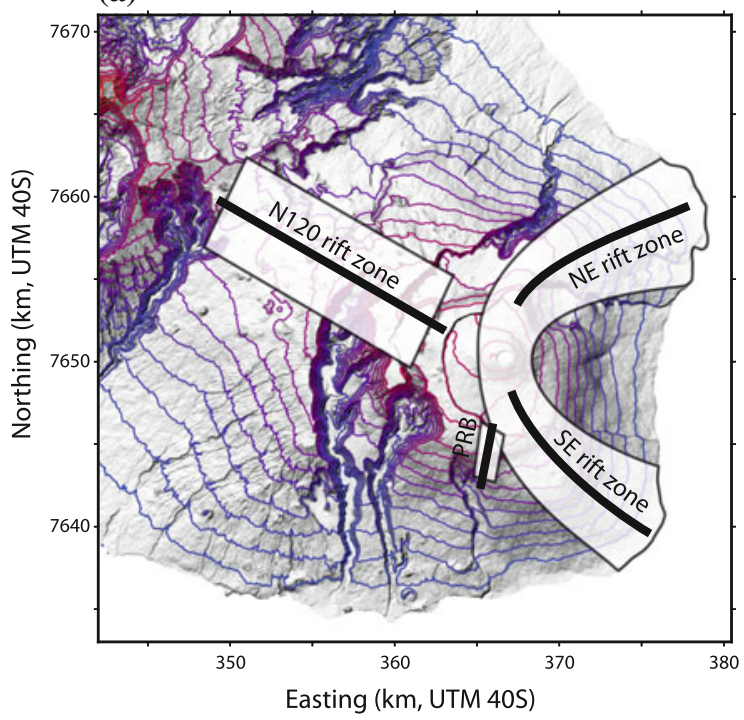

(b)

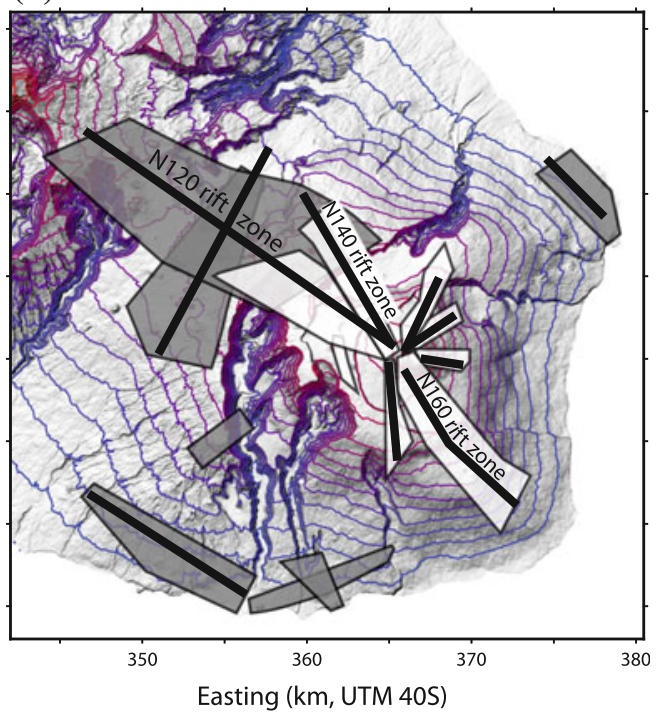

Fig. 7.1 Rift zone distribution determined for Piton de la Fournaise from a the concentration of the scoria cones (Bachèlery 1981; Villeneuve and Bachèlery 2006) and b the distribution and asymmetry of the scoria cones (Bonali et al. 2011). White and grey zones account for recent and old rift zones, whose distinction is based on the degradation stage of the scoria cones. PRB: Puys Ramond Baril volcanic alignment. $P d R$ Plaine des Remparts. $R d R$ Rivière des Remparts

on the volcano flanks, and most of the N120 rift zone lying between Piton des Neiges and Piton de la Fournaise, were considered as inactive and related to the volcano's ancient history (Fig. 7.1b; Bonali et al. 2011). All the active rift zones were connected to the summit of Piton de la Fournaise. 

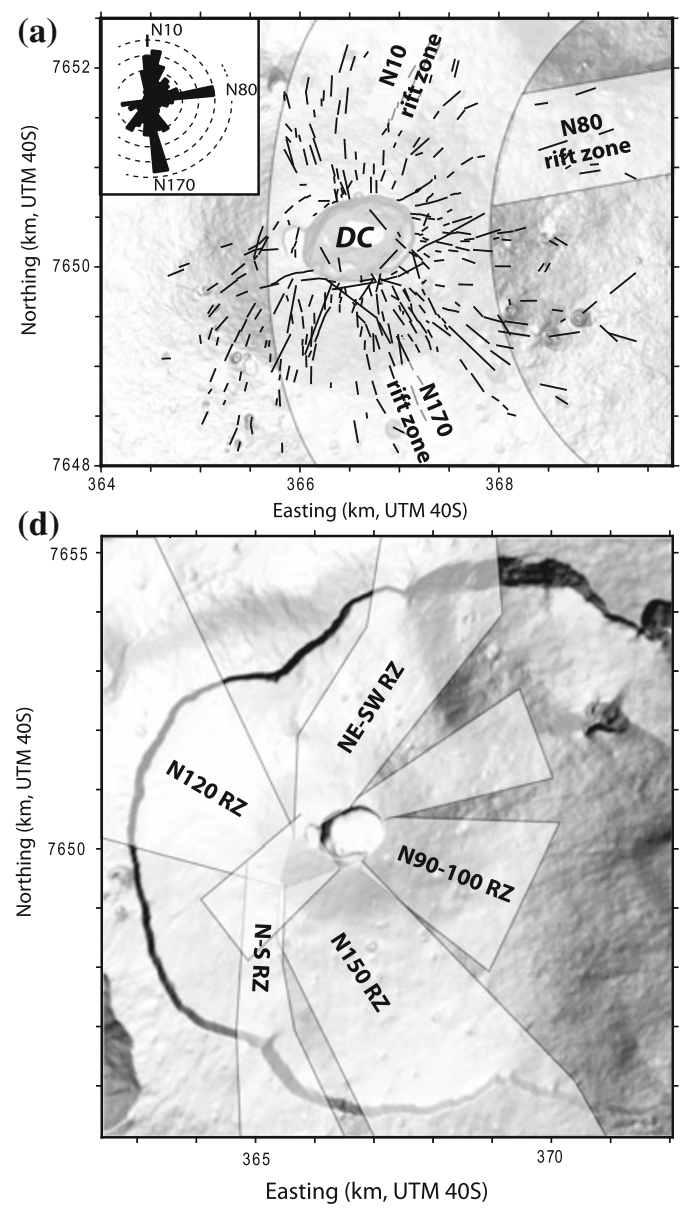

Fig. 7.2 a Distribution and main orientations of the eruptive fissures opened in the Central Cone of Piton de la Fournaise, enabling to determine two main N10 and N170 rift zones North and South of the Dolomieu caldera (DC), respectively (after Bachèlery 1981). b N25-30 and N120 rift zones inferred from the orientation of recent dykes (black lines) intruding the Central Cone between 1981 and 2006 (after Michon et al. 2009). c Distribution of radial

\subsubsection{Magma Paths Centred on the Enclos Fouqué Caldera}

Seismological data indicate that above $7.5 \mathrm{~km}$ below sea level (b.s.l.), the plumbing system is almost exclusively restricted to the Enclos Fouqué caldera (Nercessian et al. 1996; Aki and Ferrazzini 2000; Battaglia et al. 2005; Prôno et al. 2009). The magmatic activity related to this part of the volcanic system progressively led to the building, on the floor of the Enclos Fouqué

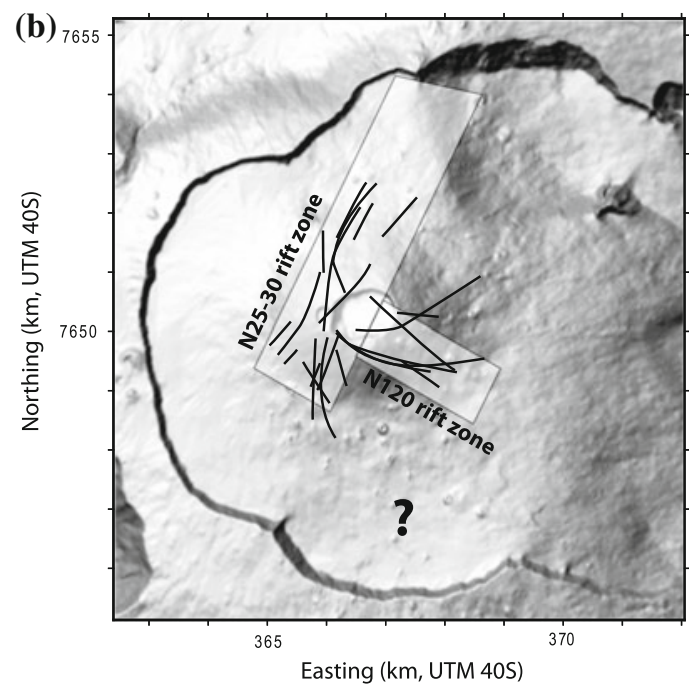

(c)

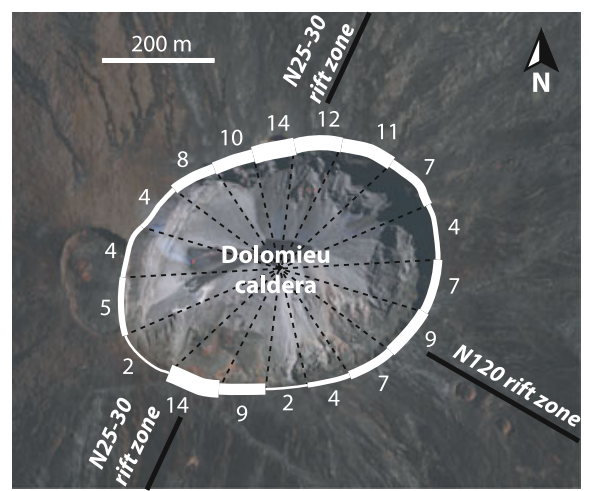

dykes in the walls of the Dolomieu caldera. Numbers refer to the dyke population detected in each of the 18 sectors. The thickness of the white line is proportional to the dyke population. The N25-30 and N120 rift zones previously determined from dyke distribution outside the caldera (Michon et al. 2009) are indicated for comparison. d Rift zone distribution determined from the scoria cone morphometry (after Fig. 12 in Bonali et al. 2011)

caldera, of the 400-m-high Central Cone capped by the Bory crater and the Dolomieu caldera (Fig. 7.2a). This cone and to a lesser extent the Enclos Fouqué caldera are cut by hundreds of eruptive fissures that formed during the recent history of Piton de la Fournaise.

Considering the eruptive fissures orientation, Bachèlery (1981), Carter et al. (2007) proposed that the main shallow intrusion paths fed by the summit plumbing system are organized in two 
main N10 and N170 rift zones located North and South of the summit craters, respectively, and in a secondary N80 rift zone on the cone's eastern flank (Fig. 7.2a). A contrasting geometry characterized by two perpendicular N25-30 and N120 rift zones has been suggested from the distribution of the dykes intruded in the Central Cone between 1981 and 2006 (Fig. 7.2b; Michon et al. 2009). This pattern is supported by the dyke distribution in the wall of the Dolomieu caldera (Fig. 7.2c; Michon et al. 2013). Finally, a much more complex rift zone distribution was recently determined from the scoria cone morphometry (Fig. 7.2d; Bonali et al. 2011). Magmas ascending through the summit plumbing system could propagate along seven radial rift zones. Noteworthily, this rift zone pattern partly corresponds to the aggregate of preferential intrusion paths described in previous works (Bachèlery 1981; Michon et al. 2007). Given the important differences in the rift zone geometries (N10/N170 arcuate rift zones, N25-30/N120 perpendicular rift zones or seven radial rift zones), it is worth wondering (1) the cause of these differences and (2) the link between the rift zones identified inside the Enclos Fouqué caldera and the NE and SE rift zones propagating outside the Enclos Fouqué.

The question arises whether these rift zones connect to a single or to different magma reservoirs. Lénat and Bachèlery (1990) explained the main characteristics of the summit eruptions, i.e. short-lived, small volume of erupted magma and a short duration between the initiation of dyke injection and the opening of eruptive fissures, as resulting from relatively small magma pockets scattered between the volcano's summit and sea level (2.6 km below volcano's summit) (Fig. 7.3). The draining of these shallow magma reservoirs during distal eruptions was thought to trigger summit collapses (pit crater) inside the Dolomieu crater like in 1986 and 2002 (Hirn et al. 1991; Longpré et al. 2007). Beside this shallow system, two distinct magma-rich zones have been (a)

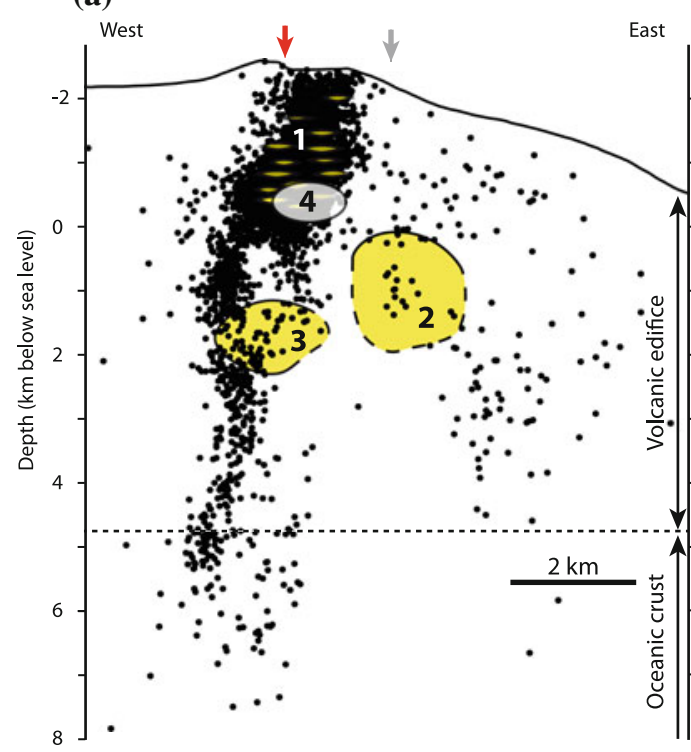

Fig. 7.3 a Seismic events related to the summit and distal eruptions between 1998 and 2010. Structures labelled 1, 2, 3 and 4 account for small magma pockets related to summit eruptions (Lénat and Bachèlery 1990), a low velocity zone inferred from Vp and Vs waves (Nercessian et al. 1996), a low velocity zone deduced from a $\mathrm{Vp}$-wave tomography

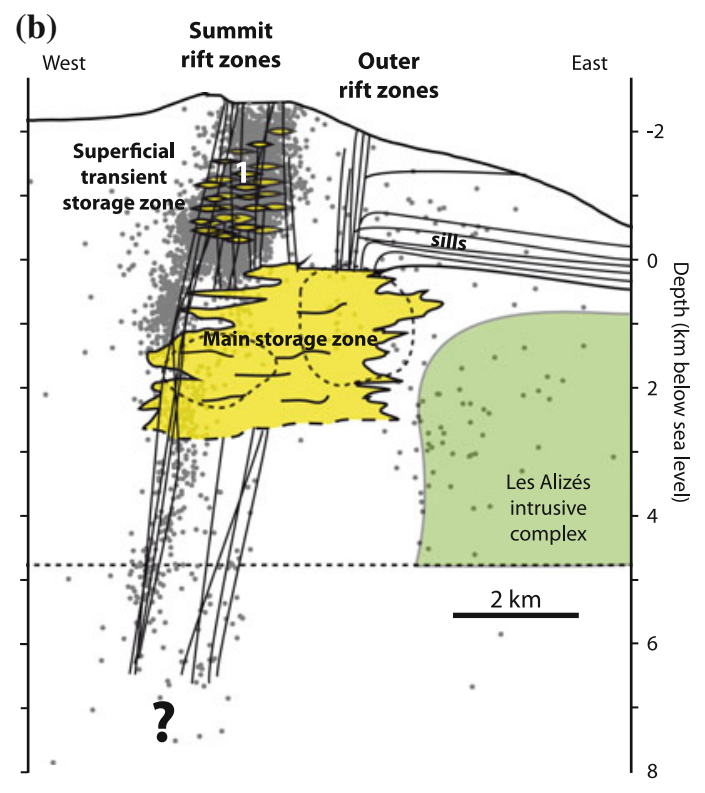

(Prôno et al. 2009) and the magma reservoir inferred from geodetic data (Peltier et al. 2008), respectively. Red and grey arrows indicate the locus of the pre-eruptive inflation related to summit and distal eruptions. b Interpretative summit plumbing system below the Enclos Fouqué caldera (see text for explanation) 
evidenced from seismic wave propagation. These low velocity bodies are located between 1-2 km depth bsl below the Bory crater (Prôno et al. 2009) or 0-2 km depth bsl, $1 \mathrm{~km}$ east of Dolomieu crater (Nercessian et al. 1996) (Fig. 7.3). Importantly, the identification of these two zones was made from two different sets of data, at two different periods, with two different networks of seismic stations. It cannot be excluded that each zone is a part of a larger structure or the same low velocity zone located at different places. Assuming a unique structure, this zone situated between sea level and $2 \mathrm{~km}$ bsl is supposed to be the locus of a transient magma storage, which feeds the most voluminous distal eruptions like in 1977, 1986 and 2007 (Nercessian et al. 1996; Prôno et al. 2009). Finally, a quite different picture has been proposed from the inversion of geodetic data (Peltier et al. 2008, 2009). According to Peltier et al. (2009), all the eruptions, except for that of 1998, are fed by a single magma reservoir, located above sea level, below the Dolomieu crater and regularly recharged by deeper sources (Fig. 7.3). However, this interpretation does not consider nor explain the intense seismicity that occurs in the proposed magma reservoir.

\subsection{Reappraisal of the Magma Paths}

In order to decipher the rift zone geometry and their current activity or inactivity, an integrated analysis of (1) the recent ( $<30$ kiloyears) volcanic cones distribution, (2) the volcano-tectonic events recorded by the Piton de la Fournaise Volcano Observatory between 1996 and 2013, and (3) the available eruption datings (Bachèlery 1981; Tanguy et al. 2011; Morandi et al. 2016) has been carried out. The density map calculated from a total of 644 scoria cones first shows a N-S elongated maximum cone concentration restricted to the Enclos Fouqué caldera, the site of most of the recent eruptions (Fig. 7.4a). This area is superimposed to a dense seismicity developed below the summit from the surface to about $7.5 \mathrm{~km}$ below sea level, tracking the magma propagation paths along the summit plumbing system (Fig. 7.5a; Aki and Ferrazzini 2000; Battaglia et al. 2005). The evolution of the April 1977, March 1986 and March 1998 eruptions, starting inside the Enclos Fouqué caldera and propagating along the NE and SE rift zones clearly indicates that these rift zones, which are

\section{(a)}

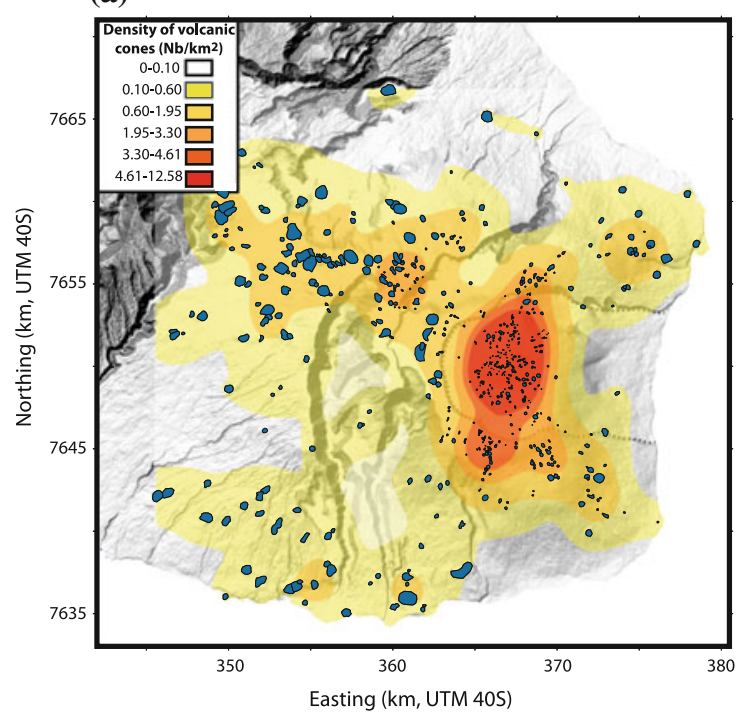

(b)

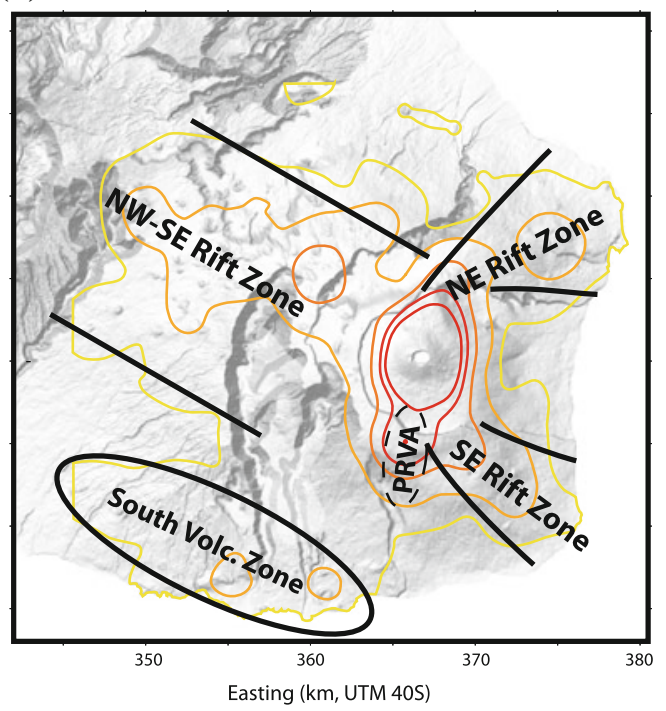

Fig. 7.4 a Density map of the scoria cones (blue) on the massif of Piton de la Fournaise younger than 60 kiloyears. b Preferential intrusion paths proposed in this study from the density map 
(a)
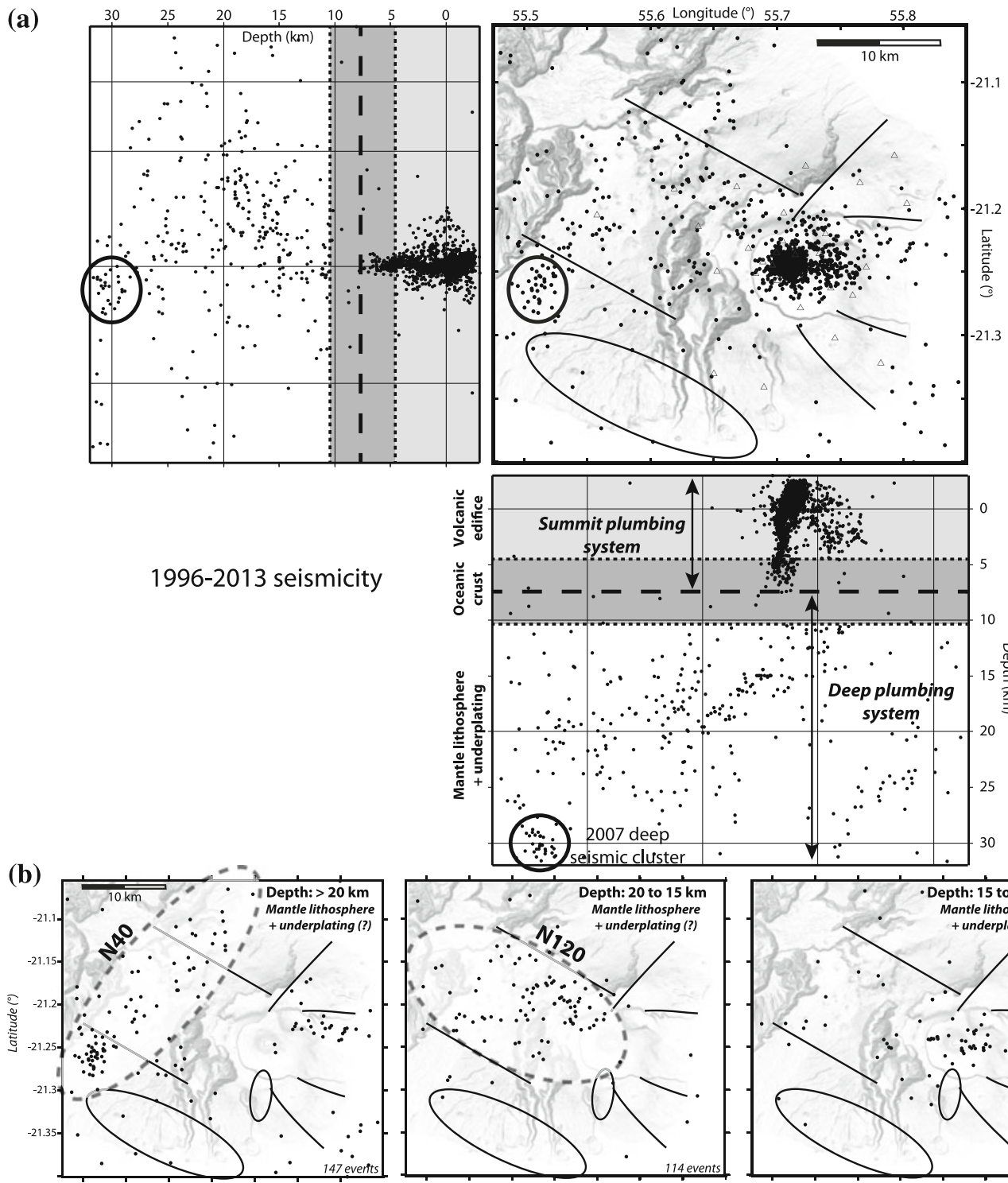

选

1996-2013 seismicity
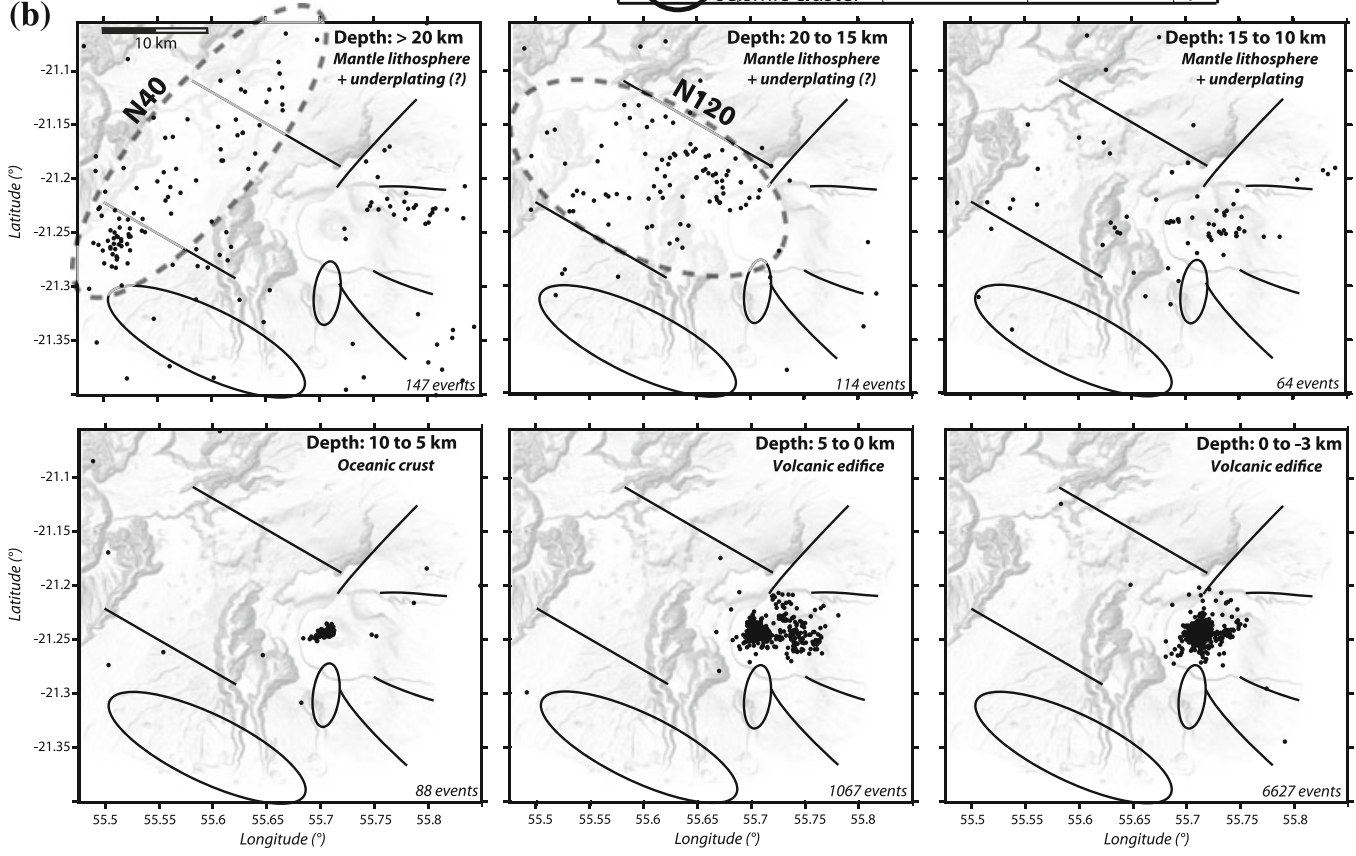

Fig. 7.5 a Volcano-tectonic seismic hypocenters (black dots) localized between 1996 and 2013 by the Piton de la Fournaise volcano observatory (OVPF/IPGP) on the massif of Piton de la Fournaise. Location is determined by a manual picking of the arrival times at different stations of the network. Depth of the top and the base of the oceanic crust is from Fontaine et al. (2012). The occurrence of underplating between 10 and $15 \mathrm{~km}$ bsl has been determined by Gallart et al. (1999). b Distribution of the seismicity at different depths. The solid lines account for the preferential intrusion paths inferred from the scoria cones distribution (Fig. 7.4) 
underlined by a larger cone concentration (Fig. 7.4a), are dynamically linked to the shallower part of the plumbing system feeding the Central Cone.

At the edifice scale, two further areas of cone concentration can be identified, corresponding to the NW-SE rift zone and the South Volcanic Zone, both trending in the N120 direction (Fig. 7.4b).

\subsubsection{The Summit Plumbing System}

Magma intrusions are strongly sensitive to the stress distribution $\left(\sigma_{3}\right.$ and $\sigma_{1}$, the least and main principal stresses, respectively). In a homogeneous volcanic cone, $\sigma_{3}$ is perpendicular to the slope and $\sigma_{1}$ varies from vertical at depth to a downslope orientation in subsurface (Dieterich 1988; Cayol and Cornet 1998; van Wyk de Vries and Matela 1998). In such an ideal cone, eruptive fissures and dykes, which correspond to tension cracks are radially distributed (Delaney and Pollard 1981; Pollard 1987). However, in nature, additional effects such as magma overpressure, rheological layering, volcano instabilities, faulting activity and structural inheritance may lead to a strongly anisotropic stress field, which influence the dyke intrusion along preferential orientations (Chadwick and Dieterich 1995; Tibaldi 1996, 2003; Walker 1999; Marinoni and Gudmundsson 2000; Walter and Troll 2003).

At Piton de la Fournaise, the en échelon pattern of the eruptive fissures related to the same eruption was interpreted as resulting from the eastern displacement of the Central Cone's eastern flank (Bachèlery et al. 1983; Lénat et al. 1989a). However a detailed inspection of the eruptive fissures opened between 1998 and 2005 in the Central Cone and the floor of the surrounding Enclos Fouqué caldera clearly shows that almost all fissures develop parallel or subparallel to the slope (Michon et al. 2007). Moreover, geophysical data suggest that the orientation of the en échelon eruptive fissures related to the same eruption can be explained by a single feeding dyke at depth (Battaglia and Bachèlery 2003; Fukushima et al. 2005; Peltier et al. 2005). Thus, the radial to subradial distribution of the eruptive fissures on the flanks of the Central Cone and on the floor of the Enclos Fouqué suggests that the fissure orientation is controlled by downslope $\sigma_{1}$ rather than by dyke orientation (Michon et al. 2007). Note that the boundary faults of the summit collapse structures also control the concentric distribution of the eruptive fissures in the summit area (Lénat and Bachèlery 1990). We therefore consider that the distribution of the eruptions intruding the Central Cone, e.g. the summit and proximal eruptions in the terminology of Peltier et al. (2008), is best explained by the N25-30 and N120 rift zones. In such a configuration, a few magma intrusions in the cone's eastern flank are controlled by N65 trending faults (Michon et al. 2009). What is the link between these summit rift zones and the much broader NE and SE rift zones on the volcano flank?

The location of the eruptions, their dynamics and the related deformation pattern for the period spanning between 1972 and 2013 have been taken into account to answer this question. During this time span, Piton de la Fournaise experienced 81 eruptions. The distribution of the eruptive fissures shows that most dykes (58) intruded the Central Cone along the N25-30 and N120 summit rift zones (Table 7.1). Summit eruptions, corresponding to both summit and proximal eruptions in the terminology of Peltier et al. (2008), are characterized by no or limited lateral dyke propagation, which usually stops at the base of the Central Cone. Exceptionally, in November 1987, September 1988 and November 2002, dykes propagated 1-2 km from the cone's base. Twenty-two eruptions, named distal eruptions, started directly on the floor of the Enclos Fouqué caldera and occasionally propagated downslope outside the Enclos Fouqué caldera (1977, 1986 and 1998) or along the northern and southern walls of the Grandes Pentes and Grand Brûlé (1976, 2002, 2005 and 2007; Table 7.1; Fig. 7.6a). Interestingly, the eruptive fissures related to distal eruptions in Table 7.1, are concentrated in three areas located South, East and North of the Central Cone. They define three preferential intrusion paths named outer rift 
Table 7.1 Eruptions of Piton de la Fournaise since 1972

\begin{tabular}{|c|c|c|c|c|}
\hline \multicolumn{2}{|l|}{ Eruption timing } & \multirow[t]{2}{*}{ Eruption type } & \multirow[t]{2}{*}{ Rift zone } & \multirow[t]{2}{*}{ Volume $\left(10^{6} \mathrm{~m}^{3}\right)$} \\
\hline Start (dd/mm/yy) & End (dd/mm/yy) & & & \\
\hline 09/06/72 & $11 / 06 / 72$ & Summit & N25-30 SRZ & 0.27 \\
\hline $25 / 07 / 72$ & $17 / 08 / 72$ & Distal & East RZ & 2.9 \\
\hline 07/09/72 & $26 / 09 / 72$ & Summit & N25-30 SRZ & 4 \\
\hline $10 / 10 / 72$ & $10 / 12 / 72$ & Distal & South-East RZ & 9.3 \\
\hline $10 / 05 / 73$ & $28 / 05 / 73$ & Summit & N120 SRZ & 1.6 \\
\hline $04 / 11 / 75$ & $18 / 11 / 75$ & Summit & N120 SRZ & 1.4 \\
\hline $18 / 12 / 75$ & $25 / 01 / 76$ & Summit & N120 SRZ & 0.03 \\
\hline $12 / 01 / 76$ & 06/04/76 & Distal & South-East RZ & 11.6 \\
\hline $02 / 11 / 76$ & $03 / 11 / 76$ & Summit & N25-30 SRZ & 0.46 \\
\hline $24 / 03 / 77$ & $24 / 03 / 77$ & Distal & South-East RZ & 0.06 \\
\hline $05 / 04 / 77$ & $16 / 04 / 77$ & Distal & North-East RZ & 20 \\
\hline $24 / 10 / 77$ & $17 / 11 / 77$ & Summit & N120 SRZ & 23 \\
\hline $28 / 05 / 79$ & $29 / 05 / 79$ & Summit & N25-30 SRZ & 0.2 \\
\hline $13 / 07 / 79$ & $14 / 07 / 79$ & Summit & N25-30 SRZ & 0.3 \\
\hline 03/02/81 & $24 / 02 / 81$ & Summit & N25-30 SRZ & 3 \\
\hline $24 / 02 / 81$ & $31 / 03 / 81$ & Summit & N25-30 SRZ & 4 \\
\hline $01 / 04 / 81$ & $05 / 05 / 81$ & Distal & East RZ & 5 \\
\hline $04 / 12 / 83$ & $18 / 01 / 84$ & Summit & N25-30 SRZ & 8 \\
\hline $18 / 01 / 84$ & $18 / 02 / 84$ & Summit & N25-30 SRZ & 9 \\
\hline $14 / 06 / 85$ & $15 / 06 / 85$ & Summit & N25-30 SRZ & 1 \\
\hline 05/08/85 & $01 / 09 / 85$ & Summit & N25-30 SRZ & 7 \\
\hline 06/09/85 & $10 / 10 / 85$ & Summit & N120 SRZ & 14 \\
\hline $01 / 12 / 85$ & $03 / 12 / 85$ & Summit & N25-30 SRZ & 0.7 \\
\hline $29 / 12 / 85$ & $07 / 02 / 86$ & Summit & N120 SRZ & 7 \\
\hline $19 / 03 / 86$ & $05 / 04 / 86$ & Distal & South-East RZ & 13.5 \\
\hline $13 / 07 / 86$ & $13 / 07 / 86$ & Summit & N120 SRZ & 0.28 \\
\hline $12 / 11 / 86$ & $13 / 11 / 86$ & Summit & N120 SRZ & 0.27 \\
\hline $26 / 11 / 86$ & $27 / 11 / 86$ & Summit & N120 SRZ & 0.24 \\
\hline $06 / 12 / 86$ & 07/01/87 & Summit & N120 SRZ & 2 \\
\hline 07/01/87 & $10 / 02 / 87$ & Distal & East RZ & 10 \\
\hline $10 / 06 / 87$ & $29 / 06 / 87$ & Summit & N120 SRZ & 1 \\
\hline $19 / 07 / 87$ & $20 / 07 / 87$ & Distal & East and South RZ & 1 \\
\hline $06 / 11 / 87$ & $08 / 11 / 87$ & Summit & N25-30 SRZ & 1.6 \\
\hline $30 / 11 / 87$ & 01/01/88 & Distal & South-East RZ & 10 \\
\hline 07/02/88 & $02 / 04 / 88$ & Distal & South-East RZ & 8 \\
\hline $18 / 05 / 88$ & 01/08/88 & Summit & N25-30 SRZ & 7 \\
\hline $31 / 08 / 88$ & $12 / 09 / 88$ & Summit & N25-30 SRZ & 4 \\
\hline $14 / 12 / 88$ & $29 / 12 / 88$ & Distal & North-East RZ & 4 \\
\hline
\end{tabular}


Table 7.1 (continued)

\begin{tabular}{|c|c|c|c|c|}
\hline \multicolumn{2}{|l|}{ Eruption timing } & \multirow{2}{*}{ Eruption type } & \multirow[t]{2}{*}{ Rift zone } & \multirow[t]{2}{*}{ Volume $\left(10^{6} \mathrm{~m}^{3}\right)$} \\
\hline Start (dd/mm/yy) & End (dd/mm/yy) & & & \\
\hline $18 / 01 / 90$ & $19 / 01 / 90$ & Summit & N120 SRZ & 0.97 \\
\hline $18 / 04 / 90$ & 08/05/90 & Distal & South-East RZ & 8 \\
\hline $19 / 07 / 91$ & $20 / 07 / 91$ & Summit & N120 SRZ & 5 \\
\hline 27/08/92 & $23 / 09 / 92$ & Summit & N120 SRZ & 5.5 \\
\hline 09/03/98 & $21 / 09 / 98$ & Summit & N25-30 SRZ & 60 \\
\hline $11 / 03 / 98$ & 01/04/98 & Other & NW-SE RZ & 0.75 \\
\hline 08/08/98 & $15 / 09 / 98$ & Distal & North-East RZ & 0.9 \\
\hline 19/07/99 & $31 / 07 / 99$ & Summit & N120 SRZ & 1.3 \\
\hline 28/09/99 & $23 / 10 / 99$ & Summit & N25-30 SRZ & 1.4 \\
\hline $13 / 02 / 00$ & 03/03/00 & Summit & N25-30 SRZ & 8.2 \\
\hline $23 / 06 / 00$ & $30 / 07 / 00$ & Distal & South-East RZ & 10 \\
\hline $12 / 10 / 00$ & $13 / 11 / 00$ & Summit & N120 SRZ & 9 \\
\hline 27/03/01 & 04/04/01 & Summit & N120 SRZ & 4.8 \\
\hline $11 / 06 / 01$ & 09/07/01 & Summit & N120 SRZ & 9.5 \\
\hline 05/01/02 & $16 / 01 / 02$ & Distal & North-East RZ & 13 \\
\hline $16 / 11 / 02$ & $03 / 12 / 02$ & Summit & N120 SRZ & 8 \\
\hline $30 / 05 / 03$ & $30 / 05 / 03$ & Summit & N25-30 SRZ & 0.16 \\
\hline 04/06/03 & 09/06/03 & Summit & N25-30 SRZ & 0.72 \\
\hline $12 / 06 / 03$ & $15 / 06 / 03$ & Summit & N25-30 SRZ & 0.59 \\
\hline $22 / 06 / 03$ & 07/07/03 & Summit & N25-30 SRZ & 0.69 \\
\hline $22 / 08 / 03$ & $27 / 08 / 03$ & Summit & N25-30 SRZ & 6.2 \\
\hline $30 / 09 / 03$ & 01/10/03 & Summit & N25-30 SRZ & 1 \\
\hline 07/12/03 & $25 / 12 / 03$ & Summit & N120 SRZ & 1.2 \\
\hline 08/01/04 & 08/01/04 & Distal & North-East RZ & 1.9 \\
\hline 02/05/04 & $18 / 05 / 04$ & Summit & N25-30 SRZ & 16.9 \\
\hline $12 / 08 / 04$ & $16 / 10 / 04$ & Summit & N120 SRZ & 20 \\
\hline $17 / 02 / 05$ & $26 / 02 / 05$ & Distal & North-East RZ & 19 \\
\hline 04/10/05 & $17 / 10 / 05$ & Summit & N25-30 SRZ & 2 \\
\hline $29 / 11 / 05$ & $29 / 11 / 05$ & Summit & N25-30 SRZ & 1 \\
\hline $26 / 12 / 05$ & 18/01/06 & Distal & North-East RZ & 20 \\
\hline 20/07/06 & $14 / 08 / 06$ & Summit & N25-30 SRZ & 2 \\
\hline 30/08/06 & 01/01/07 & Summit & N120 SRZ & 20 \\
\hline $18 / 02 / 07$ & $19 / 02 / 07$ & Summit & N120 SRZ & 1 \\
\hline $30 / 03 / 07$ & $31 / 03 / 07$ & Distal & South-East RZ & 0.6 \\
\hline 02/04/07 & 01/05/07 & Distal & South-East RZ & 240 \\
\hline $21 / 09 / 08$ & 02/10/08 & Summit & N25-30 SRZ & 1 \\
\hline $27 / 11 / 08$ & $28 / 11 / 08$ & Summit & N25-30 SRZ & 0.1 \\
\hline $14 / 12 / 08$ & 04/02/09 & Summit & N25-30 SRZ & 1.5 \\
\hline
\end{tabular}


Table 7.1 (continued)

\begin{tabular}{l|l|l|l|l}
\hline \multicolumn{2}{l}{ Eruption timing } & Eruption type & Rift zone & Volume $\left(10^{6} \mathrm{~m}^{3}\right)$ \\
\hline Start $(\mathrm{dd} / \mathrm{mm} / \mathrm{yy})$ & End $(\mathrm{dd} / \mathrm{mm} / \mathrm{yy})$ & & & \\
\hline $05 / 11 / 09$ & $06 / 11 / 09$ & Summit & N120 SRZ & 0.14 \\
\hline $14 / 12 / 09$ & $15 / 12 / 09$ & Summit & N25-30 SRZ & 0.16 \\
\hline $02 / 01 / 10$ & $12 / 01 / 10$ & Summit & N25-30 SRZ & 1.2 \\
\hline $14 / 10 / 10$ & $31 / 10 / 10$ & Distal & South-East RZ & 2.7 \\
\hline $09 / 12 / 10$ & $10 / 12 / 10$ & Summit & N25-30 SRZ & 0.53 \\
\hline
\end{tabular}

Emitted volumes from Peltier et al. (2009), Roult et al. (2012)

zones, that are spatially disconnected from the summit rift zones; the South-East, East and North-East rift zones that gather 12, 4 and 7 distal eruptions respectively (Fig. 7.6). These rift zones roughly correspond to the NE and SE rift zones and the N80 intrusion path identified by Bachèlery (1981). The important new observation brought by the present work is that the outer rift zones are solely fed by distal eruptions rather than by all eruption types. According to Peltier et al. (2009), between 1998 and 2007, proximal and distal eruptions were fed by two distinct vertical pathways, located below the western and eastern part of the Dolomieu caldera, respectively, and connected to a single magma reservoir lying at about $2300 \mathrm{~m}$ depth below the Dolomieu caldera. The inclinometers data recorded during the eruptions of 1983, 1984, 1985, 1986, 1988, 1990 and 1992 also suggest two different inflation sources located below the western part of Dolomieu and below the eastern flank of the Central Cone for the summit and distal eruptions, respectively (Fig. 7.3; Delorme et al. 1989; Lénat et al. 1989a, b; Toutain et al. 1992; Delorme 1994). We consequently propose that magma intrusions feeding the summit and distal eruptions not only follow different vertical pathways but also propagate laterally along two distinct systems of rift zones, the summit and outer rift zones (Fig. 7.6b). Considering the geophysical data (Nercessian et al. 1996; Prôno et al. 2009), the dynamics of the summit and distal eruptions (Lénat and Bachèlery 1990) and the observations made in the incised Piton des Neiges volcano (Famin and Michon 2010; Chaput et al. 2014a), we tentatively propose the existence of a single main magma storage below sea level (Fig. 7.3b). This magmatic zone feeds a superficial storage system below the Central Cone that is involved during the summit eruptions. Magma injections from the eastern part of the main magmatic system occasionally occur, forming sill intrusions that act as detachment levels capable to trigger lateral flank displacement (Michon and Famin 2010; Chaput et al. 2014b) and subsequent dyke intrusions along the outer rift zones.

Finally, among the 81 eruptions, the MarchApril 1998 Hudson eruption did not follow the summit or outer rift zones. Its magma chemical composition, similar to that of the eccentric cones of the NW-SE rift zone (Pietruszka et al. 2009; Lénat et al. 2012), and its location south-west of the Central Cone suggest that the magma intrusion was not controlled by the summit or distal rift zones but instead followed the NW-SE rift zone.

\subsubsection{The NW-SE Rift Zone, the South Volcanic Zone and the Deep Plumbing System}

The scoria cone density map clearly shows that eruptions occurred along the NW-SE rift zone and the South Volcanic Zone, both trend in the N120 direction (Fig. 7.4b). The NW-SE rift zone, $15 \mathrm{~km}$ in width, is composed of about 160 scoria cones and pit craters scattered between the Enclos Fouqué caldera in the east and the eastern slopes of Piton des Neiges in the west. The volcanic activity started at least 29 kiloyears ago (McDougall 1971) and continued until recently (140 yr BP for Piton Rampe 14), given an 
Fig. 7.6 a Eruptive fissures formed between 1972 and 2010 (black), summit dykes for the period between 1981 and 2007 (red, after Michon et al. 2009) and summit rift zones channeling the summit eruptions. Dates indicate the eruptive vents opened outside the Enclos Fouqué caldera or close to the northern and southern walls of the Grandes Pentes. b Distribution of the outer (grey) and summit (light red) rift zones related to the distal and summit eruptions, respectively. Red and grey circles indicate the location of the edifice inflation triggered by magma intrusions before the summit and distal eruptions, respectively
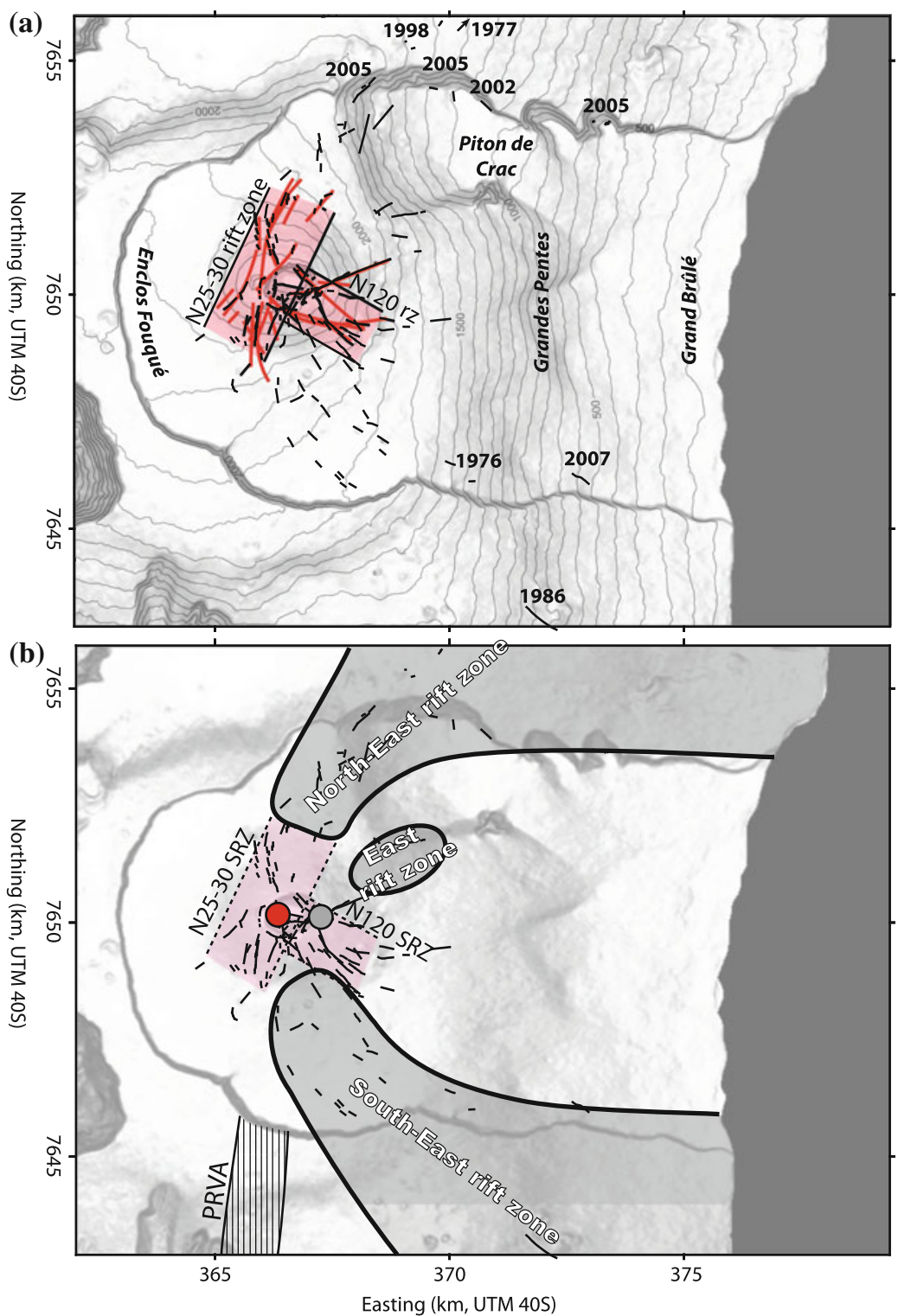

average eruption periodicity of around 200 years (Morandi et al. 2016; Chap. 8). Interestingly, the NW-SE rift zone is superimposed to a deep seismicity concentrated in a N120 trending zone ranging mostly between 15 and $20 \mathrm{~km}$ bsl, i.e. in the mantle lithosphere, just below the oceanic crust (Fig. 7.5). This seismicity is particularly active north of the Plaine des Remparts where the cone density is maximum. It is also worth noting that below $20 \mathrm{~km}$ bsl, the seismicity is organized in an orthogonal direction joining Le Tampon, the Plaine des Cafres and the Plaine des Palmistes (Fig. 7.5b).

A link between the current deep seismicity and the pre-historical scoria cones may exist only if (1) the volcano-tectonic events are associated with magma transfer instead of purely tectonic (a-magmatic) processes and (2) magmas involved in the eruptions along the NW-SE rift zone originate from at least $15 \mathrm{~km}$ in depth. Such a relationship is supported by the following geophysical and geochemical data. First, during the April 2007 
major eruption, the seismicity progressively migrated down to $7 \mathrm{~km}$ bsl. The migration continued after the eruption along the NW-SE rift zone, down to about $30 \mathrm{~km}$ below sea level (Fig. 7.5a; Massin 2009). A similar downward migration of the seismicity was recorded during the Eyjafjallajökul 2010 eruption, where it was interpreted as resulting from a downwardpropagating decompression of the plumbing system (Tarasewicz et al. 2012). Second, magma involved in the eruptions along the NW-SE rift zone indicates a high-pressure $(>0.4 \mathrm{GPa})$ fractionation of clinopyroxene \pm olivine (Kornprobst et al. 1984; Albarède et al. 1997; Famin et al. 2009; Lénat et al. 2012), which is consistent with the depth of the earthquakes located below the rift zone (depth $>15 \mathrm{~km}$ ). Third, high-pressure fluid inclusions ( $\mathrm{P}$ up to $400-500 \mathrm{MPa}$ ) are common olivine carried by magmas erupted along the N120 rift zone (Piton des Cailles; Chisny; Bureau et al. 1998). Combining these geochemical and geophysical data, we tentatively interpret the deep zone of dense seismicity below the Plaine des Cafres and Plaine des Palmistes, in the west, and the NW-SE rift zone toward the east as the deep plumbing system of Piton de la Fournaise. This zone of magma transfer could feed recurrent eruptions and subsequently form a deeply rooted NW-SE rift zone characterized by a low eruption rate.

Contrary to the NW-SE rift zone, the 20-km-long South Volcanic Zone is not associated with recent seismic events. The wide range of degradation stages of the large volcanic cones and the related lava flows, from smooth - recent - to incised-old-morphologies, suggests a recurrent volcanic activity along this intrusion path. Yet, the lack of chronological data combined with the location of the volcanic zone in apparent disconnection with the active volcanic area makes the origin and the dynamics of this volcanic zone enigmatic.

An additional, short vent alignment, the Puys Ramond-Baril volcanic alignment, occurs south of the Enclos Fouqué by the density map (Fig. 7.4b). This narrow, 10-km-long area is composed of several spatter and cinder conesthat are in average significantly smaller than those of the NW-SE rift zone and the South Volcanic Zone, but similar to those found in the Enlos Fouqué and along the SE and NE rift zones. Radiocarbon datings and the occurrence of dykes and buried cones in the southern wall of the Enclos Fouqué caldera indicate a long-lasting activity, which developed until recently (355 BP; Bachèlery 1981; Tanguy et al. 2011; Morandi et al. 2016, Chap. 8). Despite its location close to the summit plumbing system, the link between this intrusion part and the summit activity and/or the SE rift zone remains unclear.

\subsection{Comparison with Other Volcanoes}

Our work clearly shows that different types of rift zone developed on Piton de la Fournaise since at least 30 kiloyears. On the one hand, the $120 \mathrm{~N}$ trending NW-SE rift zone and the South Volcanic Zone present strong similarities with the rift developed in the post shield phase in Mauritius and Hawaii alkaline postshield rift zones in Hawaii (Clague 1987; Moore et al. 2011). In all these cases, they correspond to wide, linear rift zones with eruptions with a secular frequency involving magmas fractionating at minimum depths of 15-20 km (Roeder 1965; Clague 1987; Albarède et al. 1997; Lénat et al. 2012). On the other hand, the arched rift zones geometry of the $\mathrm{NE}$ and SE outer rift zones resembles to that of the NE and S rift zones of Mount Etna (Kieffer 1975). Following the model proposed by Swanson et al. (1976) for Kilauea, Bachèlery (1981), Duffield et al. (1982), Lénat et al. (1989b) postulated that the recurrent dyke intrusions along the NE and SE rift zones forcefully push the east flank and subsequently triggered the lateral collapse of the eastern flank of Piton de la Fournaise. However, determining whether or not dyking along the outer rift zones of Piton de la Fournaise actively pushes the east flank or if it passively follows the upper boundaries of a sliding sectors, like at Mount Etna (Acocella et al. 2003; Neri et al. 2005) requires at least a thorough inspection of the rift zone and eruption 
dynamics, which is beyond the scope of this review. Recent work carried out on Piton des Neiges volcano, the inactive twin of Piton de la Fournaise, suggests that rift zone development and flank landslides are linked by a common process, sill injections below the volcano flanks that act as detachment (Famin and Michon 2010; Chaput et al. 2014a).

\section{References}

Acocella V, Behncke B, Neri M, D’Amico S (2003) Link between major flank slip and 2002-2003 eruption at Mt. Etna (Italy). Geophys Res Lett 30(24). doi:10. 1029/2003GL018642

Aki K, Ferrazzini V (2000) Seismic monitoring and modeling of an active volcano for prediction. J Geophys Res 105(B7):16617-16640

Albarède F, Luais B, Fitton G, Semet M, Kaminski E, Upton B, Bachèlery P, Cheminée JL (1997) The geochemical regimes of Piton de la Fournaise volcano (Réunion) during the last 530,000 years. J Petrol 38 (2):171-201

Bachèlery P (1981) Le Piton de la Fournaise (Ile de la Réunion). Etude volcanologique, structurale et pétrologique. Unpublished Ph.D. thesis, pp 215, Univ. Clermont-Ferrand II, Clermont-Ferrand, France

Bachèlery P, Chevallier L, Gratier JP (1983) Caractères structuraux des éruptions historiques du Piton de la Fournaise (Ile de la Réunion). C R Acad Sci Paris 296:1345-1350

Battaglia J, Bachèlery P (2003) Dynamic dyke propagation deduced from tilt variations preceding the March 9, 1998, eruption of the Piton de la Fournaise volcano. J Volcanol Geoth Res 120:289-310

Battaglia J, Ferrazzini V, Staudacher T, Aki K, Cheminée JL (2005) Pre-eruptive migration of earthquakes at the Piton de la Fournaise volcano (Réunion Island). Geophys J Int 161(2):549-558. doi:10.1111/j.1365246X.2005.02606.x

Bonali FL, Corazzato C, Tibaldi A (2011) Identifying rift zones on volcanoes: an example from La Réunion island. Indian Ocean Bull Volcanol 73(3):347-366. doi:10.1007/s00445-010-0416-1

Bureau H, Pineau F, Metrich N, Semet M, Javoy M (1998) A melt and fluid inclusion study of the gas phase at Piton de la Fournaise volcano (Reunion Island). Chem Geol 147:115-130

Carter A, Wyk de Vries B, Kelfoun K, Bachèlery P, Briole P (2007) Pits, rifts and slumps: the summit structure of Piton de la Fournaise. Bull Volcanol 69 (7):741-756. doi:10.1007/s00445-006-0103-4

Cayol V, Cornet FH(1998) Three-dimensionnal modeling of the 1983-1984 eruption at Piton de la Fournaise volcano, Réunion Island. J Geophys Res 103:18025-18037
Chadwick WW, Howard KA (1991) The pattern of circumferential and radial eruptive fissures on the volcanoes of Fernandina and Isabela islands. Galapagos Bull Volcanol 53(4):259-275

Chadwick W, Dieterich J (1995) Mechanical modeling of circumferential and radial dike intrusion on galapagos volcanoes. J Volcanol Geoth Res 66:37-52

Chaput M, Famin V, Michon L (2014a) Deformation of basaltic shield volcanoes under co-intrusive stress permutations. J Geophys Res Solid Earth 119. doi:10. 1002/2013JB010623

Chaput M, Pinel V, Famin V, Michon L (2014b) Cointrusive shear displacement by sill intrusion in a detachment: a numerical approach. Geophys Res Lett 41. doi:10.1002/2013GL058813

Clague DA (1987) Hawaiian xenolith populations, magma supply rates, and development of magma chambers. Bull Volcanol 49:577-587

Delaney PT, Pollard DD (1981) Deformation of host rocks and flow of magma during growth of minette dikes and -bearing intrusions near Ship Rock, New Mexico. US Geol Surv Prof Pap 1202:1-61

Delorme H (1994) Apport des déformations à la compréhension des mécanismes éruptifs: le Piton de la Fournaise. Unpublished HDR Thesis pp. 615. University Paris VII

Delorme $\mathrm{H}$, Bachèlery $\mathrm{P}$, Blum PA, Cheminée JL, Delarue JF, Delmond JC, Him A, Lépine JC, Vincent PM, Zlotnicki J (1989) March 1986 eruptive episodes at Piton de la Fournaise volcano (Reunion Island). J Volcanol Geoth Res 36:199-208

Dieterich JH (1988) Growth and persistence of Hawaiian volcanic rift zones. J Geophys Res 93(B5):4258-4270

Duffield WA, Stieljes L, Varet J (1982) Huge landslide blocks in the growth of Piton de la Fournaise, La Réunion, and Kilauea Volcano, Hawaii. J Volcanol Geoth Res 12:147-160

Famin V, Michon L (2010) Volcano destabilization by magma injections in a detachment. Geology 38 (3):219-222

Famin V, Welsch B, Okumura S, Bachèlery P, Nakashima S (2009) Three differentiation stages of a single magma at Piton de la Fournaise volcano (Reunion hot spot). Geochem Geophys Geosyst 10 (1). doi:10.1029/2008GC002015

Fiske RS, Jackson ED (1972) Orientation and growth of Hawaiian volcanic rifts: the effect of regional structure and gravitational stress. Proc Roy Soc London Series A 329:299-320

Fontaine FR, Barruol G, Tkalcic H, Haugmard M (2012) Mapping crustal structure variation beneath the Piton de la Fournaise volcano. Abstract T31B-2590 presented at 2012 Fall Meeting. AGU. San Francisco, California, pp 3-7

Fukushima Y, Cayol V, Durand P (2005) Finding realistic dike models from interferometric synthetic aperture radar data: the February 2000 eruption at Piton de la Fournaise. J Geophys Res Solid Earth 110(B3). doi:10.1029/2004JB003268 
Gallart J, Driad L, Charvis P, Sapin M, Hirn A, Diaz J, de Voogd B, Sachpazi M (1999) Perturbation to the lithosphere along the hotspot track of La Réunion from an offshore-onshore seismic transect. J Geophys Res 104(B2):2895-2908

Hirn A, Lépine J, Sapin M, Delorme H (1991) Episodes of pit-crater collapse documented by seismology at Piton de la Fournaise. J Volcanol Geoth Res 47:89-104

Kieffer G (1975) Sur l'existence d'une 'rift zone' à l'Etna (Sicile). C R Acad Sci Paris 280:263-266

Kornprobst J, Boivin P, Lénat JF, Bachèlery $\mathrm{P}$, Bonneville A, Dupont P, Lecointre J, Seidel JL, Thomas P, Vincent PM (1984) Le Piton de la Fournaise, île de la Réunion. Colloque Prévision et Surveillance des Eruptions Volcaniques. Clermont-Ferrand, pp 75-82

(C.N.R.S.-I.N.A.G.)

Lénat JF, Bachèlery P, Bonneville A, Hirn A (1989a) The beginning of the 1985-1987 eruptive cycle at Piton de la Fournaise (La Réunion); New insights in the magmatic and volcano-tectonic systems. J Volcanol Geoth Res 36:209-232

Lénat JF, Vincent P, Bachèlery P (1989b) The off-shore continuation of an active basaltic volcano: piton de la Fournaise (Reunion Island, Indian Ocean): structural and geomorphological interpretation from Sea Beam mapping. J Volcanol Geoth Res 36:1-36

Lénat JF, Bachèlery P (1990) Structure and dynamics of the central zone of Piton de la Fournaise volcano. In: Lénat JF (ed) Le volcanisme de la Réunion, Monographie. Cent. De Rech. Volcanol, Clermont Ferrand, pp 257-296

Lénat JF, Bachèlery P, Merle O (2012) Anatomy of Piton de la Fournaise volcano (La Réunion, Indian Ocean). Bull Volcanol 74:1945-1961. doi:10.1007/s00445012-0640-y

Longpré MA, Staudacher T, Stix J (2007) The November 2002 eruption at Piton de la Fournaise volcano, La Réunion Island: ground deformation, seismicity, and pit crater collapse. Bull Volcanol 69(5):511-525. doi:10.1007/s00445-006-0087-0

MacDonald GA (1972) Volcanoes. Prentice-Hall Inc Englewood Cliffs, New Jersey, 510 pp

McDougall I (1971) The geochronology and evolution of the young volcanic island of Réunion (Indian Ocean). Geochim Cosmochim Acta 35:261-288

Marinoni LB, Gudmundsson A (2000) Dykes, faults and palaeostresses in the Teno and Anaga massifs of Tenerife (Canary Islands). J Volcanol Geoth Res 103 (1):83-103

Massin F (2009) Transferts et Stockages Magmatiques au Piton de la Fournaise. unpublished Ph.D. thesis, Université de la Réunion, St Denis, France, pp 176

Michon L, Saint-Ange F, Bachèlery P, Villeneuve N, Staudacher T (2007) Role of the structural inheritance of the oceanic lithosphere in the magmato-tectonic evolution of Piton de la Fournaise volcano (La Reunion Island). J Geophys Res Solid Earth 112: B04205. doi:10.1029/2006JB004598

Michon L, Cayol V, Letourneur L, Peltier A, Villeneuve N, Staudacher T (2009) Edifice growth, deformation and rift zone development in basaltic setting: insights from Piton de la Fournaise shield volcano (Reunion Island). J Volcanol Geoth Res 184:14-30. doi:10.1016/j. jvolgeores.2008.11.002

Michon L, Di Muro A, Villeneuve N, Saint-Marc C, Fadda P, Manta F (2013) Explosive activity of the summit cone of Piton de la Fournaise volcano (La Réunion island): a historical and geological review. J Volcanol Geoth Res 263:117-133. doi:10.1016/j. jvolgeores.2013.06.012

Montgomery-Brown EK, Sinnett DK, Larson KM, Poland MP, Segall P, Miklius A (2011) Spatiotemporal evolution of dike opening and décollement slip at Kīlauea Volcano, Hawaii. J Geophys Res 116(B3). doi:10.1029/2010JB007762

Moore J, White WM, Paul D, Duncan RA, Abouchami W, Galer SJG (2011) Evolution of shield-building and rejuvenescent volcanism of Mauritius. J Volcanol Geoth Res 207(1-2):47-66. doi:10. 1016/j.jvolgeores.2011.07.005

Morandi A, Di Muro A, Principe C, Michon L, Leroi G, Norelli F, Bachèlery P (2016) Pre-historic explosive activity at Piton de la Fournaise volcano. In: Bachèlery P, Lénat JF, Di Muro A, Michon L (eds) Active volcanoes of the Southwest Indian Ocean: Piton de la Fournaise and Karthala. Active Volcanoes of the World. Springer, Berlin

Nercessian A, Hirn A, Lépine JC, Sapin M (1996) Internal structure of Piton de la Fournaise volcano from seismic wave propagation and earthquake distribution. J Volcanol Geoth Res 70(3-4):123-143

Neri M, Acocella V, Behncke B, Maiolino V, Ursino A, Velardita R (2005) Contrasting triggering mechanisms of the 2001 and 2002-2003 eruptions of Mount Etna (Italy). J Volcanol Geoth Res 144(1-4):235-255. doi:10.1016/j.jvolgeores.2004.11.025

Peltier A, Ferrazzini V, Staudacher T, Bachèlery P (2005) Imaging the dynamics of dyke propagation prior to the 2000-2003 flank eruptions at Piton de la Fournaise, Reunion Island. Geophys Res Lett 32(22). doi:10. 1029/2005GL023720

Peltier A, Famin V, Bachèlery P, Cayol V, Fukushima Y, Staudacher T (2008) Cyclic magma storages and transfers at Piton de la Fournaise volcano (La Réunion hotspot) inferred from deformation and geochemical data. Earth Planet Sci Lett 270(3-4):180-188. doi:10. 1016/j.eps1.2008.02.042

Peltier A, Bachèlery P, Staudacher T (2009) Magma transport and storage at Piton de la Fournaise (La Réunion) between 1972 and 2007: a review of geophysical and geochemical data. J Volcanol Geoth Res 184(1-2):93-108. doi:10.1016/j.jvolgeores.2008. 12.008

Pietruszka AJ, Hauri EH, Blichert-Toft J (2009) Crustal contamination of mantle-derived magmas within Piton de la Fournaise, Réunion Island. J Petrol 50:661-684

Pollard DD (1987) Elementary fracture mechanics applied to the structural interpretation of dykes. In: Halls HC, Fahrig WF (eds) Mafic dyke swarms. Geological Association of Canada Special Paper, vol 34, pp 5-24 
Prôno E, Battaglia J, Monteiller V, Got JL, Ferrazzini V (2009) P-wave velocity structure of Piton de la Fournaise volcano deduced from seismic data recorded between 1996 and 1999. J Volcanol Geoth Res 184(1-2):49-62. doi:10.1016/j.jvolgeores.2008.12.009

Roedder E (1965) Liquid $\mathrm{CO}_{2}$ inclusions in olivine-bearing nodules and phenocrystsfrom basalts. Am Min 50:1746-1782

Roult G, Peltier A, Taisne B, Staudacher T, Ferrazzini V, Di Muro A, team TO, (2012) A new comprehensive classification of the Piton de la Fournaise activity spanning the 1985-2010 period. Search and analysis of short-term precursors from a broad-band seismological station. J Volcanol Geoth Res 241-242: 78-104. doi:10.1016/j.jvolgeores.2012.06.012

Swanson DA, Duffield WA, Fiske RS (1976) Displacement of the south flank of Kilauea volcano: the result of forceful intrusion of magma into the rift zones. US Geol Surv Prof Pap 963:39 p

Tanguy JC, Bachèlery P, Le Goff M (2011) Archeomagnetism of Piton de la Fournaise: bearing on volcanic activity at La Réunion Island and geomagnetic secular variation in Southern Indian Ocean. Earth Planet Sci Lett 303(3-4):361-368. doi:10.1016/j.epsl.2011.01.019

Tarasewicz J, White RS, Woods AW, Brandsdóttir B, Gudmundsson MT (2012) Magma mobilization by downward-propagating decompression of the Eyjafjallajökull volcanic plumbing system. Geophys Res Lett 39(19). doi:10.1029/2012GL053518
Tibaldi A (1996) Mutual influence of diking and collapses at Stromboli volcano, Aeolian Arc, Italy. Geol Soc London Spec Publ 110:55-63

Tibaldi A (2003) Influence of volcanic cone morphology on dikes, Stromboli, Italy. J Volcanol Geoth Res 126:79-95

Toutain JP, Bachèlery P, Blum PA, Cheminée JL, Delorme H, Fontaine L, Kowalski P, Taochy $\mathrm{P}$ (1992) Real time monitoring of vertical ground deformations during eruptions at Piton de la Fournaise. Geophys Res Lett 19(6):553-556

van Wyk de Vries B, Matela R (1998) Styles of volcano-induced deformation: numerical models of substratum flexure, spreading and extrusion. J Volcanol Geoth Res 81(1-2):1-18

Villeneuve N, Bachèlery P (2006) Revue de la typologie des éruptions au Piton de la Fournaise, processus et risques volcaniques associés. Cybergeo: European $\mathbf{J}$ Geography. http://cybergeo.revues.org/2536)

Walker GPL (1999) Volcanic rift zones and their intrusion swarms. J Volcanol Geoth Res 94(1-4):21-34

Walter TR, Troll VR (2003) Experiments on rift zone evolution in unstable volcanic edifices. J Volcanol Geoth Res 127(1-2):107-120. doi:10.1016/S0377-0273(03) 00181-1

WalterTR, Troll VR, Cailleau B, Belousov A, Schmincke HU, Amelung F, Bogaard P (2005) Rift zone reorganization through flank instability in ocean island volcanoes: an example from Tenerife, Canary Islands. Bull Volcanol 67(4):281-291. doi:10.1007/s00445-004-0352-z 